\title{
Non-native aquatic animals introductions have driven disease emergence in Europe
}

\author{
Edmund J. Peeler ${ }^{1,{ }^{*}}$, Birgit C. Oidtmann ${ }^{1}$, Paul J. Midtlyng ${ }^{2}$, Laurence Miossec ${ }^{3}$ \\ and Rodolphe E. Gozlan ${ }^{4}$
}

\footnotetext{
${ }^{1}$ Centre for Environment, Fisheries and Aquaculture Science, Barrack Rd., The Nothe, Weymouth DT4 8UB, UK

${ }^{2}$ Norwegian School of Veterinary Science, Dep., NO-0033, 8146 Oslo, Norway

${ }^{3}$ Ifremer, rue de l'île d'Yeu, BP 21105, 44311 Nantes, France

${ }^{4}$ School of Applied Sciences, Bournemouth University, Dorset House, Talbot Camps, Fern Barrow, Poole, Dorset BH12 5BB, UK

*: Corresponding author : Edmund J. Peeler, email address : ed.peeler@cefas.co.uk
}

\begin{abstract}
:
In this paper it is argued, using examples of disease emergence in aquatic animals in Europe, that the introduction of non-native species drives disease emergence by both extending the geographic range of parasites and pathogens and facilitating host-switching. Enteric red mouth disease and infectious haematopoietic necrosis of salmonids have extended their geographic range from North America to Europe with the import of live fish (Pimephales promelas) and rainbow trout eggs, respectively. Hostswitching results in disease emergence when previously unidentified commensal organisms or known pathogen switch to new naïve hosts. The most serious endemic diseases of wild aquatic animals in Europe in recent years can be traced to the introduction of non-native species. Across Europe dramatic populations declines have occurred in native crayfish (e.g. Astacus astacus), oysters (Ostrea edulis) and eels (Anguilla anguilla), all which can be attributed, in varying degrees, to diseases (crayfish plague, Bonamia ostreae and Anguillicoloides crassus, respectively) introduced with nonnative species. The severe adverse effects at a population level can be attributed to the lack of immunity in the new hosts. The impact of parasites more recently introduced to Europe, Sphaerothecum destruens (the rosette agent), and Batrachochytrium dendrobatidis, have yet to be fully determined. Both are generalists, with wide host ranges, and may present serious threats to native species. Aquaculture is the key driver for the introduction of non-native species. Most farming systems allow pathogen exchange between farmed and wild populations which underpins hostswitching. Subsequently movements of animals between farms may result in the spread of newly emerged diseases. The introduction of non-native aquatic animals drives disease emergence, thus the ex-ante assessment of these hazards is severely limited. Generic risk mitigation measures (e.g. movement of disinfected eggs in place of live animals) and improved methods for rapid detection of new diseases are vital.
\end{abstract}

Keywords : Aquaculture ; Transmission ; Control ; Pathways ; Virulence ; Fish 


\section{Introduction}

Aquaculture production and the range of species farmed (which include crustaceans, molluscs and finfish) have increased significantly over the last two decades (Food and Agriculture Organisation (FAO), http://www.fao.org/fi/statist/statit.asp accessed on 15/12/08). Salmonid farming has expanded rapidly in Northern Europe, North America and Chile, mirrored by increases in farmed sea bream (Sparus aurata) and seabass (Dicentrarchus labrax) in the Mediterranean (Ariel and Olesen 2002). Nevertheless, Asia, and especially China still dominate world-wide farmed fish and shellfish production (FAO 2008). Aquatic animals are mainly farmed for food but also for stock enhancement, recreational fishing and the pet trade. The expansion of aquaculture in recent years has depended on the use of non-native species. Rainbow trout (Oncorynchus mykiss) are indigenous to North America but are now farmed in South America, Europe, Asia and Australia (Maccrimmon 1971). Similarly, the Pacific Oyster Crassostrea gigas (Ruesink et al. 2005) has a wide distribution across the globe and is the most important farmed species of shellfish in Europe. The phenomenal growth in penaeid shrimp farming, periodically constrained by disease outbreaks (Hill 2002), has been based on the culture of species outside of their natural range. The trade in ornamental aquatic animals has also resulted in large scale movements of live aquatic animals to countries outside of their natural range (Gozlan 2008). On a similar scale live molluscs and crustaceans, intended for human consumption, are moved internationally.

The economic benefits of non-native introductions are undeniable (Gozlan 2008); however, there are ecological risks. The deliberate or accidental introduction of non-native aquatic animal species has caused a range of environmental impacts (e.g. predation, competition, hybridisation, habitat use) (Ruiz et al. 1997). Codes of practice have been developed to mitigate the likelihood and consequences of non-native species introduction (FAO 2005; FAO and NACA 2000). The environmental threats of non-native aquatic animals motivated the European Commission to pass 'Council Regulation No. 708/2007, which requires that approval to introduce non-native species is supported by a risk assessment.

In recent years, the rate of disease emergence in human (Jones et al. 2008) and animal populations has increased (Daszak et al. 2000), and emerging diseases have become an increasingly important area of research in both human (Krause 1998) and animal health (Daszak et al. 2001b), including aquatic animals (Harvell et al. 1999). Human activities, including the introduction of non-native species, have altered many ecosystems, in some cases seriously reducing ecosystem function (Chapin et al. 2000) and possibly leading to disease emergence (Woolhouse and Gowtage-Sequeria 2005). However, it has been argued that few studies have examined whether or how ecological change may influence disease emergence (Plowright et al. 2008). There is strong evidence that the introduction of pathogens into new areas through human activities (pathogen pollution) is one of the most important factor driving disease emergence in wildlife populations (Daszak et al. 2001a). In this paper disease emergence resulting from the movement of non-native aquatic animal species into Europe are reviewed. The impact of these diseases on native species is considered in the context of generalist and specialist pathogens. The challenges to risk assessment, the management of non-native introductions and disease in wildlife populations are discussed.

In this paper the term parasite will be used as a collective term for pathogens (also known as micro-parasites, such as viruses and bacteria) and macro-parasites, such as nematodes and cestodes. 


\section{Types of disease emergence}

Emerging diseases have been defined as recently increasing in incidence, geographic range or virulence, recently moved into a new host, newly discovered or caused by a newly evolved pathogen (Brown 2000; Daszak et al. 2000). The movement of non-natives may spread identified parasites which are also known as transboundary diseases (Hedrick 1998). Known parasites may also exploit their new environment by switching host (i.e. crossing the species barrier); this may occur with or without evolutionary change through mutation. Commensal micro-organisms (previously unidentified) may emerge as new parasites having switched to a new host (Murray and Peeler 2005). Host switching requires contact between the putative parasites and a new host species. Secondly, host barriers to infection (e.g. immune response) must be overcome and the infection established, before efficiently spreading within the new host population (Parrish et al. 2008). Pathogens may be more virulent (i.e. increase ability to cause disease) in a new host due to a lack of innate immunity (compare with the original host). More virulent parasites may also emerge, without host switching, if conditions favour their selection (see Mennerat et al. 2010 for a discussion on the impact of intensive fish farming on the evolution of virulence). The categories of emerging disease are not mutually exclusive. By switching hosts a parasite may extend its geographic range, through live animal movements of the new host. The introduced original host may act as a reservoir population from which infection can 'spill-over' to sympatric wildlife (Gozlan et al. 2005). In the long term this may allow for evolutionary change to take place which results in host switching or increased virulence (Parrish et al. 2008).

\section{What is a non-native aquatic animal species?}

Despite attempts to achieve common definitions of terms, difficulties remain due to the combination of ecological and political criteria being used to identify species as 'native' or 'non-native' (Davis and Thompson 2000; Shafland and Lewis 1984). Most scientific publications use national boundaries to determine whether a species is native or non-native, irrespective of its biogeography. The term translocation is often used to differentiate between within- and across-country movements. However, in ecological terms a species moved from one river drainage basin to another within the same country could generate similar ecological outcomes as a species moved across national borders. The International Union for Conservation of Nature (IUCN) and the Convention on Biological Diversity (CBD) recommend that native species are determined at the level of the ecosystem, and not by political borders; both organisations define non-native species as a species introduced outside its natural range (Riley 2005). The same reasoning can be applied to parasites. They also have an original geographic distribution, largely determined by the presence of the natural host(s), with which the parasite has co-evolved.

\section{Drivers for the movement of non-native aquatic animals}

Aquatic animals may be translocated outside of their natural geographic range for a number of reasons (see Table 1) but aquaculture is the main driver. In addition the movement of aquatic animals, fertilised eggs are moved in large volumes and internationally for salmonid aquaculture. Whilst moving this life stage is safer than moving live animals, the transmission of disease is still possible. It is estimated that over 1 billion ornamental fish comprising more than 4000 freshwater and 1400 marine species from over 100 countries are traded internationally each year (Whittington and Chong 2007). Little is known of their disease 
status. Most pet aquatic animals are kept in secure closed systems, however, some are released into the wild and survive (Copp et al. 2007).

Live molluscs and crustaceans, and to a far lesser extent fish, are traded internationally for human consumption. Such animals may be diverted for use in culture, or be disposed of in the aquatic environment potentially leading to the establishment of their parasites. Volumes of trade.

\section{Emergence of known parasites in new hosts}

The large majority of cases of disease emergence in European aquatic animals (Table 2) are attributable to host-switching. Anguillicoloides crassus (a nematode) which was introduced to Europe through the importation of Asian eels Anguilla japonica from Japan to Germany for fattening and consumption (Koops and Haartmann 1989). Whilst the exotic eels did not escape the parasite succeeded in infecting wild European eels Anguilla anguilla (Koops and Haartmann 1989). A. crassus first emerged in European eels which had been translocated to Asia (Kirk 2003).

It has been suggested that gaffkaemia (caused by Aerococcus viridans) was introduced to the UK with the import of live North American lobsters Homarus americanus for human consumption (Alderman, 1996). The imported lobsters were held in open seawater holding facilities which allowed the bacteria to spill over into the wild native lobster population (Alderman, 1996). The disease sporadically affects native European lobsters (Stebbing et al, submitted for publication).

The introduction of a large number of macro-parasites to the UK due to ornamental fish introductions has been reviewed by Kennedy (1993). However, none is yet to cause serious disease epidemics, their impact in native species has been confined to localised mortalities. By contrast, one of the most emerging important diseases affecting wild Atlantic salmon (Salmo salar) is caused by a macroparasites, Gyrodactylus salaris. Emergence occurred in the early 1970s following its introduction to Norway from Sweden with Atlantic salmon smolts destined for aquaculture (Mo 1994). The parasite was first described from Atlantic salmon in a hatchery on the Baltic coast of Sweden (Malmberg 1957). For many years, there were occasional findings of the parasite in Swedish salmon farms but no observations of severe disease, or findings in wild fish (Malmberg and Malmberg 1991). The switch from its original host, a Baltic strain of Atlantic salmon to Atlantic strains of Atlantic salmon resulted in disease emergence and illustrates the need to use the term of non-native with an ecological perspective. Whilst Baltic and Atlantic strains of Atlantic salmon meet the criteria necessary to class them as a single species, they have been geographically separated for thousands of years. Genetic differences have arisen, some of which are due to co-evolution with parasites. Thus movement of animals from a geographically isolated to another population of the same species (e.g. Atlantic salmon from Sweden to Norway, see Table 1) may carry a similar risk of parasite introduction as a non-native introduction. These movements may not be scrutinised to the same degree of introductions of non-native species, and are likely to be more frequent.

The international trade in amphibians for food, as zoo animals, pets, laboratory animals and biological control has been implicated in the spread of spread the fungus Batrachochytrium dendrobatidis (Daszak et al. 2003). The fungus is consistently carried by the North American bullfrogs (Lithobates catesbeianus, previously Rana catesbeiana) (Garner et al. 2006). It was detected in the UK in 2004 in an introduced population of North American bullfrogs in Kent (Cunningham et al. 2005) and is known to be established in at least five other 
European countries (Garner et al. 2005). The fungus has a wide host range which explains its success in establishing in so many countries (Daszak et al. 1999).

The introduction of ranaviruses (family Iridioviridae) to Europe is also likely to have been due to imports of amphibians for ornamental purposes; the virus has been detected in frogs imported to the UK for the ornamental trade (Barry Hill, pers comm.). It emerged in Europe by host switching to native amphibians toads (Bufo bufo) in the UK (Hyatt et al. 2000) and the edible frog (Rana esculenta) in Croatia (Fijan et al 1991). Outside of Europe, trade in ornamental fish has been associated with the introduction of iridoviruses into Australia (Whittington and Chong 2007).

The ornamental trade has resulted in the accidental introduction of hitchhiker (or non-target species) which may also carry non-native parasites. Pseudorasbora parva, the topmouth gudgeon, was accidentally introduced to Europe from Asia with imports of carp (Crypinus carpio) for ornamental purposes (Pinder and Gozlan 2003). It has recently been shown to be a healthy carrier of the rosette agent Sphaerothecum destruens (Gozlan et al., 2005; Gozlan et al., 2006). It appears that the parasite was introduced to the UK with topmouth gudgeon and but is presence only became apparent once it had infected sunbleak (Leucaspius delineatus) in which it appears to cause wasting and reduced fecundity (Gozlan et al., 2005; Gozlan et al., 2006).

\section{Emergence of new parasites}

Only one example of a new parasite emerging as a non-native introductions to Europe was identified. Bonamia oestreae emerged in Ostrea edulis Europe during the late 1970s and early 1980s (Elston et al. 1986). Later the parasite was discovered in Californian, where studies indicated it originated (Elston et al. 1986). It is believed that the parasite was introduced into France and Spain with spat of $O$. edulis, the European flat oyster, produced in a hatchery in California (USA) (Comps et al. 1980). O. edulis was first introduced from Holland into the west coast of USA at the end of the 1940s (Loosanoff 1955). Thus the parasite was introduced into Europe through the reintroduction of a native species from outside its natural geographic range. When an aquatic animal species is moved outside its natural range not only may it introduce parasites to a range of new potential hosts, the nonnative species is itself exposed to a new range of potential parasites. The case of $O$. edulis, illustrates that the reintroduction of a species back to its country of origin carries a similar risk of parasite introduction as a truly non-native species. It is reasonable to assume switching from its original host, possibly Crassostrea virginica (O.I.E. 2009), underpinned emergence in $O$. edulis.

\section{Geographic spread of known parasites}

There are a few examples of diseases which spread to Europe years after they initially emerged in other parts of the world. Yersinia ruckeri (the bacteria causing enteric redmouth in salmonids) emerged in rainbow trout production in the 1950s in the US. It appears to have spread initially to France (Lesel et al. 1983) with the importation of minnows (Pimephales promelas) which were used for live-baiting in the early 1980s (Michel et al. 1986). The pathogen has become established in rainbow trout culture throughout Europe (Horne and Barnes 1999).

Similarly IHNV emerged in salmonids production in Oregon in the 1950s (Wolf 1988) and was introduced to Europe in the 1980s. On this occasion the route of introduction appears to 
have been the import of rainbow trout eggs for use in aquaculture (Bovo et al. 1987). The hypothesis has been supported by molecular epidemiology studies showing that all European IHNV isolates belong to one of the four North American genogroups, and suggest a single introduction (Enzmann et al. 2005).

The haplosporidian parasite Haplosporidium nelsoni was first identified in 1993 in C. gigas collected in two bays in France (Renault et al. 2000). H. nelsoni is suspected to have been introduced into France with spat and adult Pacific oysters imported from Japan and British Colombia (Canada) respectively in the 1970s. There is no recorded spread to native European species.

\section{Routes of establishment}

Following emergence, the likelihood that the parasite establishes and spreads will partly be determined by how the host population is maintained. Compared with other routes of parasite introduction (e.g. fish carcasses), non-native species introduction is likely to result in parasite establishment since the parasite is introduced with its host. Establishment of the parasite in native species requires contact (direct or via water) between a potential new host and the infected non-native species. This may occur if the non-native species is deliberately (e.g. for recreational fishing or biological control) or accidentally (e.g. escapees) introduced into a wild environment. Escapes from aquaculture or ornamental facilities have been well documented for many non-native species, which may have been deliberately (i.e. target species) or accidentally (hitchhiker or non-target species) introduced. Rainbow trout escapees from aquaculture are commonly found around farms. Deliberate (and often illegal) introductions of aquatic animals into the wild also take place, and have been particularly well documented for ornamental fish (Copp et al., 2007).

The open design of many aquaculture systems permits the exchange of parasites between farmed and wild aquatic animal populations without direct contact between hosts (Kent 2000). Thus, whilst species introduced for aquaculture may be kept in conditions which prevent their escape, excreted parasites will be disseminated via water currents exposing endemic species in the vicinity (e.g. downstream of a farm using river water). Following introduction, $A$. crassus and $A$. viridans both succeeded in establishing in wild native species, whilst their non-native hosts ( $A$. japonicus and $H$. americanus) did not establish in the wild. Land based recirculation systems are the exception; effluent is disinfected, e.g. by ozone treatment, from which the likelihood of parasite dissemination is very low.

\section{Parasite dissemination following introduction}

The movement of live animals is generally the most important for widespread, long distance dissemination of parasites (Peeler et al. 2004). The scale of impact of new and introduced pathogens will in large part be determined by the extent of its geographic distribution. The movement of live fish is an integral part of many production systems. In Europe rainbow trout production is organised around specialist hatcheries that supply juvenile fish ("fingerlings") to a large number of producers for ongrowing. Detailed investigations (Johnsen and Jensen 1988) concluded that nearly all Norwegian rivers affected by G. salaris could be traced to the release of salmon from one Norwegian hatchery where the parasite was first discovered in 1975, the accidental release of infected fish from a truck transport, or with secondary spread to neighbouring watercourses via short-distance migrations through brackish water. Similarly $A$. crassus has been spread through eel restocking programmes and movement of wild caught eels for farming (Kirk 2003). Whilst crayfish plague was introduced in the 1860s 
(probably through the discharge of ballast water or import of fish carrying fungal spores in their gut), the spread of crayfish plague in Europe accelerated once signal crayfish (the nonnative host) were brought to Europe to be farmed in the 1960s (Alderman, 1996). Topmouth gudgeon, a healthy carrier of the rosette agent Sphaerothecum destruens (Gozland et al., 2005) has become the most invasive fish species in Europe, with what has become a pan European distribution, through movement of other species (e.g. carp) to fisheries and for ornamental purposes (Pinder and Gozlan 2003).

Shellfish farming is also based on large-scale animal movements. Oyster farmers transfer oyster batches between areas to optimize yields. Moreover movements of oyster spat (authorised and illegal), produced naturally and in hatcheries also occur between European countries. This has resulted in the rapid and widespread distribution of $B$. ostreae throughout European shellfish production areas and natural beds (McArdle et al. 1991). Recently the emergence of a new strain of oyster herpes virus 1 disease in France, which was associated with high levels of summer mortality in C. gigas (Pepin et al. 2009) spread to Jersey (Reid, A. pers comm.) and Ireland (Geoghagen, F., pers. com.) through movements of live oysters for relaying. Oysters may also be moved accidentally spreading disease. Two loughs in Ireland, Lough Foyle and Lough Swilly, have recently been found to be positive for Bonamia ostreae (Culloty and Mulcahy 2007). An epidemiological investigation concluded that a batch of mussels containing flat oyster spat was the likely route of introduction (Culloty and Mulcahy 2007); an example of a hitch-hiker (non-target organism) spreading disease within a country. Boats and equipments can also disseminate parasites in oysters attached to the hulls or carried by dredges (Howard 1994). Sharing equipment between sites is thought to have resulted in the spread of IHN virus in France and in British Columbia (HattenbergerBaudouy et al. 1995; St-Hilaire et al. 2002). Anguilloides crassus was also probably spread to the UK via the movement of transport lorries from mainland Europe to collect elvers, which were carrying free living larval stages (Kennedy and Fitch 1990)

Slaughterhouses and processing plants may also be hubs of disease dissemination (Munro et al. 2003). Parasites can be disseminated locally if discharged effluent is not disinfected. Observational studies (Jarp and Karlsen 1997) revealed that distance to slaughterhouses were an important risk factor for infectious salmon anaemia (ISA) in farmed Atlantic salmon in Norway. There is inconclusive evidence that waste from imported crustacean resulted in white spot syndrome virus (WSSV) introduction, possibly via birds scavenging landfill sites (Vanpatten et al. 2004).

\section{Generalist versus specialist parasites and the impact of emerging diseases}

Disease spread and emergence due to the movement of non-natives has disproportionably affected wild, not farmed, aquatic animal populations in Europe over recent years. The lack of natural immunity to introduced parasites has resulted in population declines and the total or virtual elimination of susceptible hosts at a local or wider scale. Atlantic salmon populations have been severely depleted in over 45 rivers in Norway due to $G$. salaris (though elimination of the parasites has been achieved in some rivers) (pers. comm. T.A. Mo). Native European crayfish, Astacus astacus L., have been virtually eliminated from large parts of Europe due to crayfish plague carried by signal crayfish, Pacifastacus leniusculus (Dana 1852) (Alderman 1996). B. ostreae has significantly contributed to the virtual elimination of native oysters from many regions of Europe (and their replacement by the Pacific oyster, C. gigas) (Culloty et al. 1999). A. crassus causes a debilitating infection in the swimbladder of European eels and may have has an important role to play in the dramatic decline in numbers over the last 20 years. It is certainly possible that infected eels are less likely to reach the Sargasso Sea to spawn. However, the decline of eels is at least partially 
due to a number of inter-related factors, including pollution, barriers to upstream migration and over-exploitation (Kirk 2003; Naismith and Knights 1990).

The potential impact of more recently introduced parasites, Sphaerothecum destruens and Batrachochytrium dendrobatidis cannot yet be fully assessed. However, both are generalist pathogens, with wide host ranges, which is a serious cause for concern. The consequences of generalism on pathogenicity are important but often overlooked (Yamamoto and Kilistoff 1979). Generalist pathogens are more likely to emerge through host-switching (Woolhouse and Gowtage-Sequeria 2005). The existence of functional fitness trade-offs for generalists should favour the evolution of specialists exploiting narrower niches. Many studies have highlighted that in single host parasites the trade-off between virulence and transmissibility determines the optimum level of virulence (Davies et al. 2001). In multi-host pathogens, depending on the level of virulence and transmissibility in each host, the introduction of a second host with a different susceptibility can lead to a change of virulence of the pathogen and thus could alter its potential transmissibility to the first host and the outcome of infection (Woolhouse et al. 2001). Sphaerothecum destruens (rosette agent) illustrates the potential threat of a generalist parasite. This intracellular parasite was recently discovered in Europe (Gozlan et al. 2005) and appears to infect wild and captive salmonid and cyprinid fish (Gozlan et al. 2009). Topmouth gudgeon is an invasive healthy carrier (i.e. reservoir host) of $S$. destruens, in which the parasite may persist whilst causing localized outbreaks of variable and unpredictable timing and magnitude in other susceptible species. The sunbleak contributes little to $S$. destruens fitness, and there should not be a selective constraint on $S$. destruens virulence in sunbleak because the topmouth gudgeon is present as a healthy carrier. This may explain why the parasite, within three years of introduction, has led to localised population extinctions of sunbleak (Gozlan et al. 2005). In addition, a number of cyprinid species have been shown under experimental conditions to be susceptible to $S$. destruens (Gozlan et al. 2009) though to date there is no evidence that these populations are regulated by the parasite in Europe.

Similar arguments may also be advanced for $B$. dendrobatidis, the cause of chytridiomycosis, a fungal disease which has been the cause of dramatic declines of a wide range of amphibian populations (Hyatt et al. 2000) in Australia and Central America (Daszak et al. 2001a). It has been detected in Europe (Garner et al. 2005) and has been associated with localised mortalities, e.g. natterjack toads (Epidalea (Bufo) calamita) in Cumbria, UK (Cunningham et al. 2005) but to date has not been associated with population declines.

\section{The limits of risk assessment and risk mitigation}

The likelihood of parasite introduction and spread with the introduction of a non-native aquatic animal species should be an integral part of a risk assessment protocol undertaken to support decision making about species introduction (FAO, 1995; FAO and NACA, 2000; Anon., 2001). However, the usefulness of risk assessment for disease introduction is limited by hazard identification (the first step). As currently applied risk assessment does not attempt to account for unidentified hazards. Parasites introduced by non-native species are very often unidentified hazards because, as discussed above, it is the non-native introduction that drives disease emergence (e.g. G. salaris, A. crassus and A. astaci were only recognised as pathogenic following a non-native introduction). Whittington and Chong (2007) made a similar point by highlighting the significant difficulties in undertaking disease import risk assessments for ornamental fish; a large number of imported species and sources, combined with little disease information. The situation may be further complicated by the presence of non-target, non-native species which themselves may carry parasites; rosette agent infections of the topmouth gudgeon being an example. It has been suggested that historical evidence on the frequency of disease emergence could be used to provide an 
estimate of the risk of unidentified hazards for use in an import risk analysis (Gaughan 2002); but this is not currently acceptable under international trade agreements (WTO 1995). The risk assessment required by the $\mathrm{EC}$ regulation 708/2007 will also only assess identified parasites.

Control of diseases in wild populations is extremely problematic and elimination is generally considered impossible; an exception being localised control of $G$. salaris and S. destruens (Britton et al. 2008; Britton et al. 2009) through the elimination of host fish species in some lakes and rivers by chemical treatment. The control of introduced parasites can be particularly problematic once established in a wild endemic population, or in a highly successful invasive species (e.g. signal crayfish, Pacifastacus leniusculus). Parasites with multiple host species, such as Batrachochytrium dendrobatidis, create further challenges. Effective disease control requires a high level of understanding of the dynamics of infectious disease in multihost populations (Cleaveland et al. 2001), especially when some species act as reservoir populations where the pathogen can be permanently maintained and difficult to detect (e.g. S. destruens in top mouth gudeon) (Haydon et al. 2002).

The introduction of non-native species clearly has potential economic benefits (Gozlan 2008). However, given the limitations of risk assessment, it is important that risk mitigation measures to reduce the likelihood of parasite transmission are thoroughly explored to minimise the potential costs that may occur from disease. Whittington and Chong (2007) recommend limiting the number of ornamental species traded and the countries of origin. Other options include quarantining non-native species with native species. Research is needed to establish the duration and conditions of quarantine most likely to reveal putative parasites. However, quarantine cannot offer a high likelihood of detection. Notwithstanding the example of IHN virus introduction to Europe via rainbow trout eggs, the movement of gametes is invariably considerably safer than moving live animals. Few aquatic animal diseases are transmitted via true intra-ovum infections, and surface disinfection (e.g. using iodine) can reduce the risk of contamination to a negligible level (the introduction of IHN virus was probably a failure to properly disinfect the eggs). Establishing a non-native species by introducing fertilised eggs instead of adult animals should always be considered.

\section{Conclusion}

Aquaculture and the ornamental aquatic animal trade are the key drivers for the introduction of non-native aquatic animal species. The movement of live animals is the main route of spread of disease spread. However, the introduction of non-native species also drives the emergence of new diseases and known diseases in new hosts by bringing parasites into contact with new potential hosts, thus facilitating host-switching. Generalist parasites, able to jump the species barrier, are more likely to emerge, compared with single host parasites. Endemic species of aquatic animals (especially wild populations) become exposed to introduced parasites due to the open nature of aquaculture production systems. Once emerged parasites have been disseminated through the large-scale movements of animals for aquaculture. The presence of the natural host facilitates emergence of disease in naïve native populations and in the longer terms may allow emergence through evolutionary change in the introduced parasite. Although there are numerous examples of disease emergence after species introduction, there are probably many more that have not been identified. Slow emergence through evolutionary changes may not so easily be associated with non-native introductions. Developments in sampling protocols and diagnostic techniques will enable better characterisation of emerging infectious pathogens. These improved methods will also underpin measures to control non-native pathogens through surveillance to establish free zones and effective legislation to prevent the movement of animals from infected areas. 
The serious adverse consequences of the introduction of parasites introduced to naive wild European aquatic animals are well documented. The impact of recent parasite introductions in amphibians is currently unfolding. Rising water temperatures, due to climate change, will increase the likelihood that introduced ornamental species, and their parasites can survive in Europe. Successful control of parasites is very unlikely once established in wild populations, thus changes generally are permanent and irreversible. It must be recognised that introducing non-native species carries a risk of non-native parasite introduction that, ex-ante, cannot be fully assessed. Without improved risk mitigation (quarantine, introduction of fertilised eggs) disease emergence as a result of non-native species introduction will continue with potentially serious consequences for wild aquatic animal populations.

\section{Acknowledgments}

The author thanks the EU IMPASSE FP7 consortium for their fruitful comments and suggestions.

\section{References}

Alderman DJ (1996) Geographical spread of bacterial and fungal diseases of crustaceans. Revue Scientific et Techique, Office International des Epizooties (OIE). 15: 603-632

Ariel $\mathrm{E}$ and Olesen NJ (2002) Finfish in aquaculture and their diseases - a retrospective view on the European Community. Bull. Eur. Assoc. Fish Pathol 22: 72-83

Balseiro P, Aranguren R, Gestal C, Novoa B and Figueras A (2006) Candidatus Xenohaliotis califomiensis and Haplosporidium montforti associated with mortalities of abalone Haliotis tuberculata cultured in Europe. Aquaculture 258: 63-72

Bovo G, Giorgetti G, Jørgensen PEV and Olesen NJ (1987) Infectious hematopoietic necrosis: First detection in Italy. Bulletin of the European Association of Fish Pathologists 7: 124

Britton JR, Brazier M, Davies GD and Chare SI (2008) Case studies on eradicating the Asiatic cyprinid Pseudorasbora parva from fishing lakes in England to prevent their riverine dispersal. Aquatic Conservation: Marine and Freshwater Ecosystems 18: 867-876

Britton JR, Davies GD and Brazier M (2009) Towards the successful control of the invasive Pseudorasbora parva in the UK. Biological Invasions: 1-7

Brown C (2000) Emerging Diseases of Animals - an Overview. In: Brown C and Bolin C (eds) Emerging Diseases of Animals, p 324, American Society for Microbiology

Chapin FS, Zavaleta ES, Eviner VT, Naylor RL, Vitousek PM, Reynolds HL, Hooper DU, Lavorel S, Sala OE, Hobbie SE, Mack MC and Diaz S (2000) Consequences of changing biodiversity. Nature 405: 234-242

Cleaveland S, Laurenson MK and Taylor LH (2001) Diseases of humans and their domestic mammals: Pathogen characteristics, host range and the risk of emergence. Philosophical Transactions of the Royal Society B: Biological Sciences 356: 991-999

Comps M, Tige $G$ and Grizel H (1980) Etudes ultrastructurale d'un protiste parasite de I'huitre Ostrae edulis L. Acad. Sci. Paris D2: 383-384

Copp GH, Templeton M and Gozlan RE (2007) Propagule pressure and the invasion risks of non-native freshwater fishes: A case study in England. Journal of Fish Biology 71: 148-159

Culloty SC and Mulcahy D (2007) Bonamia oestreae in the native oyster Ostrea edulis - a review. Marine Environment and Health Series, p 40, University College, Cork 
Culloty SC, Novoa B, Pernas M, Longshaw M, Mulcahy MF, Feist SW and Figueras A (1999) Susceptibility of a number of bivalve species to the protozoan parasite Bonamia ostreae and their ability to act as vectors for this parasite. Diseases of Aquatic Organisms 37: 73-80

Cunningham AA, Garner TWJ, Aguilar-Sanchez V, Banks B, Foster J, Sainsbury AW, Perkins M, Walker SF, Hyatt $A D$ and Fisher MC (2005) Emergence of amphibian chytridiomycosis in Britain. Veterinary Record 157: 386-387

Daszak P, Berger L, Cunningham AA, Hyatt AD, Earl Green D and Speare R (1999) Emerging infectious diseases and amphibian population declines. Emerging Infectious Diseases 5: 735-748

Daszak P, Cunningham AA and Hyatt AD (2000) Emerging infectious diseases of wildlife threats to biodiversity and human health. Science 287: 443-449

Daszak P, Cunningham AA and Hyatt AD (2001a) Anthropogenic environmental change and the emergence of infectious diseases in wildlife. Acta Tropica 78: 103-116

Daszak P, Cunningham AA and Hyatt AD (2001b) Emerging infectious diseases of wildlife threats to biodiversity and human health. Science 287: 443-449

Daszak P, Cunningham AA and Hyatt AD (2003) Infectious disease and amphibian population declines. Diversity and Distributions 9: 141-150

Davies CM, Webster JP and Woolhouse MEJ (2001) Trade-offs in the evolution of virulence in an indirectly transmitted macroparasite. Proceedings of the Royal Society B: Biological Sciences 268: 251-257

Davis MA and Thompson K (2000) 8 ways to be a colonizer, 2 ways to be an invader: A proposed nomenclature scheme for invasion ecology. Bulletin of the Ecological Society of America,: 226-230

Elston RA, Farley CA and Kent ML (1986) Occurrence and significance of bonamiasis in European flat oysters Ostrea edulis in North America. Diseases of Aquatic Organisms 2: 4954

Enzmann PJ, Kurath G, Fichtner D and Bergmann SM (2005) Infectious hematopoietic necrosis virus: Monophyletic origin of European IHNV Isolates from North-American Genogroup M. . Diseases of Aquatic Organisms 66

FAO (2005) Identification of risks and management of invasive alien species using the IPPC framework. Proceedings of the Workshop on invasive alien species and the International Plant Protection Convention, p xii + 301 pp., FAO, Braunschweig, Germany

FAO (2008) The state of world fisheries and aquaculture. p 176, United Nations Food and Agriculture Organisation, Rome

FAO and NACA (2000) The Asia Regional Technical Guidelines on Health Management for the Responsible

Movement of Live Aquatic Animals and The Beijing Consensus and Implementation Strategy. Fisheries Technical Paper, p 53, FAO, Rome.

Fijan, N., Matasin, Z., Petrinec, Z., Valpotic, I. and Zwillenberg, L.O. 1991. Isolation of an iridoviruslike agent from the green frog (Rana esculenta L). Veterinary Archives Zagreb 3, 151-158.

Garner TWJ, Perkins MW, Govindarajulu P, Seglie D, Walker S, Cunningham AA and Fisher MC (2006) The emerging amphibian pathogen Batrachochytrium dendrobatidis globally infects introduced populations of the North American bullfrog, Rana catesbeiana. Biology Letters 2: 455-459

Garner TWJ, Walker S, Bosch J, Hyatt AD, Cunningham AA and Fisher MC (2005) Chytrid fungus in Europe. Emerging Infectious Diseases 11: 1639-1641 
Gaughan DJ (2002) Disease-translocation across geographic boundaries must be recognized as a risk even in the absence of disease identification: the case with Australian Sardinops. Reviews in Fish Biology and Fisheries 11: 113-123

Gozlan RE (2008) Introduction of non-native freshwater fish: Is it all bad? Fish and Fisheries 9: $106-115$

Gozlan RE, St.-Hilaire S, Feist SW, Martin P and Kent ML (2005) Biodiversity: Disease threat to European fish. Nature 435: 1046

Gozlan RE, Peeler EJ, Longshaw M, et al. (2006) Effect of microbial pathogens on the diversity of aquatic populations, notably in Europe. Microb. Infect. 8:1358-1364

Gozlan RE, Whipps CM, Andreou D, et al. (2009) Identification of a rosette-like agent as Sphaerothecum destruens, a multi-host fish pathogen. Int. J. Parasitol. 39:1055-1058

Harvell CD, Kim K, Burkholder JM, Colwell RR, Epstein PR, Grimes DJ, Hofman EE, Lipp EK, Osterhaus ADME, Overstreet RM, Porter JW, Smith GW and Vasta GR (1999) Emerging marine diseases - climate links and anthropogenic factors. Science: 1505-1510

Hattenberger-Baudouy AM, Danton M, Merle G and De Kinkelin P (1995) Epidemiology of infectious haematopoietic necrosis (IHN) of salmonid fish in France: Study of the course of natural infection by combined use of viral examination and seroneutralization test and eradication attempts. Veterinary Research 26: 256-275

Haydon DT, Cleaveland S, Taylor LH and Laurenson MK (2002) Identifying reservoirs of infection: A conceptual and practical challenge. Emerging Infectious Diseases 8: 1468-1473

Hedrick RP (1998) Relationships of the host, pathogen, and environment: Implications for diseases of cultured and wild fish populations. Journal of Aquatic Animal Health 10: 107-111

Hill BH (2002) National and international impacts of white spot disease of shrimp. Bull. Eur. Assoc. Fish Pathol 22: 58-65

Horne MT and Barnes AC (1999) Enteric Redmouth (Yersinia ruckeri). In: Woo PTK and Bruno DW (eds) Fish diseases and disorders, Volume 3: Viral, Bacterial and Fungal Infections, pp 455-478, CABI publishing, Wallingford

Howard AE (1994) The possibility of long distance transmission of Bonamia by fouling on boat hulls. Bulletin of the European Association of Fish Pathologists 14: 211-212

Hyatt AD, Gould AR, Zupanovic Z, Cunningham AA, Hengstberger S, Whittington RJ, Kattenbelt J and Coupar BEH (2000) Comparative studies of piscine and amphibian iridoviruses. Archives of Virology 145: 301-331

Jarp J and Karlsen E (1997) Infectious salmon anaemia (ISA) risk factors in sea-cultured Atlantic salmon Salmo salar. Diseases of Aquatic Organisms 28: 79-86

Johnsen BO and Jensen AJ (1988) Introduction and establishment of Gyrodactylus salaris Malmberg, 1957, on Atlantic salmon, Salmo salar L., fry and parr in the River Vefsna, northern Norway. Journal of fish diseases 11: 35-45

Johnsen BO and Jensen AJ (1991) The Gyrodactylus story in Norway. Aquaculture 98: 289302

Jones KE, Patel NG, Levy MA, Storeygard A, Balk D, Gittleman JL and Daszak P (2008) Global trends in emerging infectious diseases. Nature 451: 990-993

Kennedy CR (1993) Introductions, spread and colonization of new localities by fish helminths and crustacean parasites in the British Isles: a perspective and appraisal. Journal of Fish Biology 43: 287-301 
Kennedy CR and Fitch DJ (1990) Colonization, larval survival and epidemiology of the nematode Anguillicola crassus, parasitic in the eel, Anguilla anguilla, in Britain. Journal of Fish Biology 36: 117-131

Kent ML (2000) Marine netpen farming leads to infections with some unusual parasites. International Journal for Parasitology 30: 321-326

Kirk RS (2003) The impact of Anguillicola crassus on European eels. Fisheries Management and Ecology 10: 385-394

Koops H and Haartmann F (1989) Anguillicola infestations in Germany and in German eel imports. Journal of Applied Ichthyology 1: 41-45

Krause RM (1998) Emerging Infections. Academic Press, New York, 513 pp

Lesel R, Lesel M, Gavini F and Vuillaume A (1983) Outbreak of enteric redmouth disease in rainbow trout, Salmo gairdneri Richardson, in France. Journal of fish diseases 6: 385-387

Loosanoff VL (1955) The European oyster in American waters. Science 121: 119-121

Maccrimmon HR (1971) World distribution of rainbow trout (Salmon gairdneri). Journal of Fisheries Board of Canada 28: 663-704

Malmberg G (1957) Om förekomsten av Gyrodactylus på Svenska fiskar. Södra Sveriges Fisheriförenging, årsskrift 1956: 19-76

Malmberg G and Malmberg M (1991) Undersøkningar angåande Gyrodactylus på laxfisk i fria vatten och odlingar under åren 1951-72 och 1986-mai 1991. Information från Søtvattenslaboratoriet, Drottningsholm. 2

McArdle JF, McKiernan F, Foley H and Jones DH (1991) The current status of Bonamia disease in Ireland. Aquaculture 93: 273-278

Mennerat A., Nilsen F., Ebert D. and Skorping A. (2010) Intensive Farming: Evolutionary Implications for Parasites and Pathogens. Evolutionary Biology, 37, 59-67.

Michel C, Faivre B and De Kinkelin P (1986) A clinical case of enteric redmouth in minnows (Pimephales promelas) imported into Europe as bait-fish. Bulletin of the European Association of Fish Pathologists 6: 97-99

Mo TA (1994) Status of Gyrodactylus salaris problems and research in Norway. In: Lewis JW (ed) Parasitic diseases of fish, pp 43-48, Samara Publishing, Tresaith, Dyfed, Wales

Munro PD, Murray AG, Fraser DI and Peeler EJ (2003) An evaluation of the relative risks of infectious salmon anaemia transmission associated with different salmon harvesting methods in Scotland. Ocean \& Coastal Management [Ocean Coast. Manage.]. 46: 1-2

Murray AG and Peeler EJ (2005) A Framework for Understanding the Potential for Emerging Diseases in Aquaculture. Preventive Veterinary Medicine 67: 223-235

Naismith IA and Knights B (1990) Modelling of unexploited and exploited populations of eels, Anguilla anguilla (L.), in the Thames Estuary. Journal of Fish Biology 37: 975-986

O.I.E. (2009) Infection with Bonamia oestrae. Manual of Diagnostic Tests for Aquatic Animals, pp 320-330, Office International des Epizooties, Paris

Parrish CR, Holmes EC, Morens DM, Park EC, Burke DS, Calisher CH, Laughlin CA, Saif LJ and Daszak P (2008) Cross-species virus transmission and the emergence of new epidemic diseases. Microbiology and Molecular Biology Reviews 72: 457-470

Peeler EJ, Gardiner R and Thrush MA (2004) Qualitative risk assessment of routes of transmission of the exotic fish parasite Gyrodactylus salaris between river catchments in England and Wales. Preventive Veterinary Medicine 64: 175-189 
Pepin JE, Segarra A, Faury N, Morga B and Renault T (2009) Summer oyster mortalities in 2008 and characterization of a new genotype in isolates of ostreid herpesvirus. In: Anon. (ed) Diseases of Fish and Shellfish, p 129, European Association of Fish Pathologists, Prague

Pinder AC and Gozlan RE (2003) Sunbleak and Topmouth Gudgeon - Two new additions to Britain's freshwater fishes. British Wildlife 15: 77-83

Plowright RK, Sokolow SH, Gorman ME, Daszak P and Foley JE (2008) Causal inference in disease ecology: Investigating ecological drivers of disease emergence. Frontiers in Ecology and the Environment 6: 420-429

Renault T, Stokes NA, Chollet B, Cochennec N, Berthe F, Gerard A and Burreson EM (2000) Halposporidiosis in the Pacific oyster Crassotrea gigas from the French Atlantic coast. Disease of Aquatic Organisms 42: 207-214

Riley S (2005) Invasive alien species and the protection of biodiversity: The role of quarantine laws in resolving inadequacies in the international legal regime. Journal of Environmental Law 17: 323-359

Ruesink J, Lenihan H, Trimble A, Heiman K, Micheli F, Byers J and Kay M (2005) Introduction of Non-Native Oysters: Ecosystem Effects and Restoration Implications. . Annual Review of Ecology:Evolution and Systematics

Ruiz GM, Carlton JM, Grosholz ED and Hines AH (1997) Global invasions of marine and estuarine habitats by non-indigenuous species: mechanisms, extend and consequences. American Zoologist 37: 621-632

Shafland P and Lewis W (1984) Terminology associated with introduced organisms Fisheries 9: 17-18

St-Hilaire S, Ribble CS, Stephen C, Anderson E, Kurath G and Kent ML (2002) Epidemiological investigation of infectious hematopoietic necrosis virus in salt water net-pen reared Atlantic salmon in British Columbia, Canada. Aquaculture 212: 49-67

Vanpatten KA, Nunan LM and Lightner DV (2004) Seabirds as potential vectors of penaeid shrimp viruses and the development of a surrogate laboratory model utilizing domestic chickens. Aquaculture 241: 31-46

Whittington RJ and Chong R (2007) Global trade in ornamental fish from an Australian perspective: The case for revised import risk analysis and management strategies. Preventive Veterinary Medicine 81: 92-116

Wolf K (1988) Infectious haematopoietic necrosis. In: Wolf K (ed) Fish Viruses and Fish Viral Diseases, pp 83-114, Cornell University Press, Ithaca, New York

Woolhouse MEJ and Gowtage-Sequeria S (2005) Host range and emerging and reemerging pathogens. Emerging Infectious Diseases 11: 1842-1847

Woolhouse MEJ, Taylor LH and Haydon DT (2001) Population biology of multihost pathogens. Science 292: 1109-1112

WTO (1995) Agreement on the Application of Sanitary and Phytosanitary Measures. p 21, World Trade Organisation, Geneva

Yamamoto T and Kilistoff $\mathrm{J}$ (1979) Infectious pancreatic necrosis virus: quantification of carriers in lake populations during a 6-year period. Journal of the Fisheries Research Board of Canada 36: 562-567 


\section{Tables}

Table 1 Reasons for the introduction of non-native aquatic animal species to Europe

Reason for introduction Example

Aquaculture

Introduction of signal crayfish (Pacifastacus leniusculus) rainbow trout (Oncorhynchus mykiss) to Europe from N. America

Slaughter and human consumption

Establishment of Pacific oysters (Crassotrea gigas) in Norway, following its introduction for human consumption

Ornamental aquatic animal Goldfish (Carasius auratus), orfe (Leuciscus idus), bitterling (Rhodeus amarus) and pumpkinseed trade (Lepomis gibbosus) are now established in the wild in the UK following introduction for ornamental purposes

Recreational fishing

Introduction of European catfish (Silurus glanis) and zander (Sander lucioperca) to the UK

Biological control Grass carp (Ctenopharyngodon idella) introduced to control weed in the UK

Laboratory use Historical trade (international) in the African clawed toad (Xenopus laevis) for pregnancy testing

Accidental

Mitten crabs (Eriocheir sinensis) to Europe (from Asia via ballast water)

Topmouth gudgeon (Pseudorasbora parva) in Europe as 'hitchhikers' from Asia with Chinese carps for aquaculture 
Table 2 Important parasite introductions to Europe via the translocation of non-native aquatic animal species

\begin{tabular}{|c|c|c|c|c|c|c|}
\hline $\begin{array}{l}\text { Infectious agent } \\
\text { (disease) }\end{array}$ & $\begin{array}{l}\text { European } \\
\text { host }\end{array}$ & $\begin{array}{l}\text { Origin of } \\
\text { infection }\end{array}$ & Year & $\begin{array}{l}\text { Non-native species } \\
\text { introduction }\end{array}$ & Impact & $\begin{array}{l}\text { Type of } \\
\text { emerging } \\
\text { disease }\end{array}$ \\
\hline \multicolumn{7}{|l|}{ Bacteria } \\
\hline $\begin{array}{l}\text { Yersina ruckeri } \\
\text { (Enteric red } \\
\text { mouth) }\end{array}$ & $\begin{array}{l}\text { Wide host range } \\
\text { (salmonids and } \\
\text { non-salmonids) }\end{array}$ & N. America & 1981 & $\begin{array}{l}\text { Minnows (Pimephales } \\
\text { promelas) imported } \\
\text { from the US to France } \\
\text { for live-baiting (Michel } \\
\text { et al. 1986). }\end{array}$ & $\begin{array}{l}\text { Serious disease in } \\
\text { rainbow trout } \\
\text { production in Europe, } \\
\text { causing a high level of } \\
\text { morbidity and } \\
\text { significant costs of } \\
\text { control }\end{array}$ & $\begin{array}{l}\text { New } \\
\text { geographic } \\
\text { area }\end{array}$ \\
\hline $\begin{array}{l}\text { Aerocaccus } \\
\text { viridans } \\
\text { (Gaffkaemia) }\end{array}$ & $\begin{array}{l}\text { European lobster } \\
\text { (Homarus } \\
\text { gammarus) }\end{array}$ & N. America & 1978 & $\begin{array}{l}\text { Live American lobsters } \\
\text { (Homarus americanus) } \\
\text { (Alderman 1996) }\end{array}$ & $\begin{array}{l}\text { No observed impact on } \\
\text { wild populations. } \\
\text { Clinical disease } \\
\text { observed in facilities } \\
\text { holding wild caught } \\
\text { animals }\end{array}$ & New host \\
\hline \multicolumn{7}{|l|}{ Viruses } \\
\hline $\begin{array}{l}\text { Infectious } \\
\text { haematopoietic } \\
\text { necrosis }\end{array}$ & $\begin{array}{l}\text { A number of } \\
\text { salmonid } \\
\text { species }\end{array}$ & N. America & 1987 & $\begin{array}{l}\text { Rainbow trout } \\
\text { (Oncorhynchus mykiss) } \\
\text { eggs (Bovo et al. 1987) }\end{array}$ & $\begin{array}{l}\text { Mortality and morbidity } \\
\text { in farmed rainbow } \\
\text { trout. No impact } \\
\text { observed in wild } \\
\text { populations }\end{array}$ & $\begin{array}{l}\text { New } \\
\text { geographic } \\
\text { area }\end{array}$ \\
\hline Ranavirus & $\begin{array}{l}\text { Amphibians, } \\
\text { reptiles and fish }\end{array}$ & $\begin{array}{l}\text { Unknown, } \\
\text { probably } \\
\mathrm{N} . \\
\text { America }\end{array}$ & $\sim 1992$ & $\begin{array}{l}\text { Imported amphibians } \\
\text { (B. Hill, pers. comm.). }\end{array}$ & $\begin{array}{l}\text { Common frog } \\
\text { mortalities in the UK } \\
\text { and localised } \\
\text { population declines } \\
\text { (Teacher et al. 2010) }\end{array}$ & New host \\
\hline \multicolumn{7}{|c|}{ Fungal and oomycete infections } \\
\hline $\begin{array}{l}\text { Aphanomyces } \\
\text { astaci (Crayfish } \\
\text { plague) }\end{array}$ & $\begin{array}{l}\text { European } \\
\text { crayfish species } \\
\text { (e.g. Astacus } \\
\text { fluviatilis, } \\
\text { Astacus } \\
\text { astacus) }\end{array}$ & N. America & $1860 \mathrm{~s}$ & $\begin{array}{l}\text { Introduction probably } \\
\text { mechanical (ballast } \\
\text { water or fish vectors) } \\
\text { (Alderman 1996); } \\
\text { reintroduction via signal } \\
\text { crayfish imports from N. } \\
\text { America in 1960s) }\end{array}$ & $\begin{array}{l}\text { High mortality of native } \\
\text { European crayfish, and } \\
\text { extinction from much } \\
\text { of their original range }\end{array}$ & New host \\
\hline $\begin{array}{l}\text { Batrachochytrium } \\
\text { dendrobatidis }\end{array}$ & $\begin{array}{l}\text { Wide host range } \\
(>13 \\
\text { amphibian } \\
\text { families) }\end{array}$ & $\begin{array}{l}\text { Unknown } \\
\text { (probably } \\
\text { the } \\
\text { Americas) }\end{array}$ & $\sim 1998$ & $\begin{array}{l}\text { Potential routes of } \\
\text { introduction to Europe } \\
\text { include movement of } \\
\text { amphibians for: pet } \\
\text { trade, zoo animals; food } \\
\text { trade; laboratory animals } \\
\text { (Daszak et al. 2003) }\end{array}$ & $\begin{array}{l}\text { Localised mortality } \\
\text { events in amphibians } \\
\text { populations (Garner } \\
\text { et al. 2005) }\end{array}$ & New host \\
\hline \multicolumn{7}{|l|}{ Parasites } \\
\hline $\begin{array}{l}\text { Sphaerothecum } \\
\text { destruens }\end{array}$ & $\begin{array}{l}\text { A number of } \\
\text { cyprinid and } \\
\text { salmonid } \\
\text { species }\end{array}$ & $\begin{array}{l}\text { Unknown, } \\
\text { probably } \\
\text { Asia }\end{array}$ & 2005 & $\begin{array}{l}\text { Topmouth gudgeon } \\
\text { (Pseudorasbora parva) } \\
\text { (Gozlan et al. 2005) }\end{array}$ & $\begin{array}{l}\text { High mortality of } \\
\text { cyprinids in particular } \\
\text { sunbleak ( } L \\
\text { delineatus) and } \\
\text { salmonids in the US } \\
\text { and salmonids in the } \\
\text { US }\end{array}$ & New host \\
\hline Bonamia oestrae & Ostrea edulis & N. America & $\begin{array}{l}\text { Late } \\
\quad 1970 \mathrm{~s}\end{array}$ & $\begin{array}{l}\text { O. oedulis }{ }^{\mathrm{a}} \text { reintroduced } \\
\text { from N. America }\end{array}$ & $\begin{array}{l}\text { Decimation of native } \\
\text { oysters }(O \text {. edulis }) \text { in } \\
\text { Europe }\end{array}$ & New disease \\
\hline
\end{tabular}


Table 2 continued

\begin{tabular}{|c|c|c|c|c|c|c|}
\hline $\begin{array}{l}\text { Infectious agent } \\
\text { (disease) }\end{array}$ & $\begin{array}{l}\text { European } \\
\text { host }\end{array}$ & $\begin{array}{l}\text { Origin of } \\
\text { infection }\end{array}$ & Year & $\begin{array}{l}\text { Non-native species } \\
\text { introduction }\end{array}$ & Impact & $\begin{array}{l}\text { Type of } \\
\text { emerging } \\
\text { disease }\end{array}$ \\
\hline $\begin{array}{l}\text { Gyrodactylus } \\
\text { salaris }\end{array}$ & $\begin{array}{l}\text { Atlantic salmon } \\
\text { (Salmo salar) }\end{array}$ & Sweden & 1973 & $\begin{array}{l}\text { Baltic strains of Atlantic } \\
\text { salmon (Johnsen and } \\
\text { Jensen 1991) }\end{array}$ & $\begin{array}{l}\text { Reduction of over } 95 \% \\
\text { in wild Atlantic } \\
\text { salmon populations in } \\
45 \text { affected rivers in } \\
\text { Norway }\end{array}$ & New host \\
\hline $\begin{array}{l}\text { Anguillicoloides } \\
\text { crassus }\end{array}$ & $\begin{array}{c}\text { European eel } \\
\text { (Anguilla } \\
\text { anguilla) }\end{array}$ & Japan & $\begin{array}{l}\text { mid } \\
1970 s\end{array}$ & $\begin{array}{l}\text { Asian eels (Anguilla } \\
\text { japonicus) (Koops and } \\
\text { Haartmann 1989) }\end{array}$ & $\begin{array}{l}\text { Mortality in infected } \\
\text { European eels, } \\
\text { potential significant } \\
\text { contribution to the } \\
\text { decline of eel } \\
\text { populations. }\end{array}$ & New host \\
\hline $\begin{array}{l}\text { Haplosporidium } \\
\text { nelsoni }\end{array}$ & $\begin{array}{l}\text { None-n Download PD } \\
\text { recorded } \\
\text { spread from the } \\
\text { introduced host }\end{array}$ & $\frac{\mathrm{F}(243.7 \mathrm{~KB})}{\mathrm{Japan}}$ or & 1993 & $\begin{array}{l}\text { Pacific oysters } \\
\text { (Crassotrea gigas) } \\
\text { (Renault et al. 2000) }\end{array}$ & $\begin{array}{l}\text { No observed impact, } \\
\text { recorded at low } \\
\text { prevalence }\end{array}$ & $\begin{array}{l}\text { New } \\
\text { geographic } \\
\text { area }\end{array}$ \\
\hline $\begin{array}{l}\text { Candidatus } \\
\text { Xenohaliotis } \\
\text { californiensis }\end{array}$ & $\begin{array}{l}\text { European } \\
\text { abalone } \\
\text { (Haliotis } \\
\text { tuberculata) }\end{array}$ & N. America & 1988 & $\begin{array}{l}\text { Red abalone (Haliotis } \\
\text { rufescens) (Balseiro } \\
\text { et al. 2006) }\end{array}$ & $\begin{array}{l}\text { Mortality juvenile } \\
\text { abalone in Galicia, } \\
\text { Spain }\end{array}$ & New host \\
\hline
\end{tabular}

${ }^{a} O$. edulis is a native species to Europe that was translocated to N. America from where it was reintroduced to France 